\title{
Genetic control of stiffness of standing Douglas fir; from the standing stem to the standardised wood sample, relationships between modulus of elasticity and wood density parameters. Part I
}

\author{
Cécile Mamdy, Philippe Rozenberg*, Alain Franc, Jean Launay, \\ Nicolas Schermann, Jean-Charles Bastien \\ Inra Orléans, 45160 Ardon, France
}

(Received 18 December 1997; accepted 1 October 1998)

\begin{abstract}
The Institut national de la recherche agronomique (Inra) developed a tree-bending machine, similar to the device elaborated by Koizumi and Ueda, and used it to measure the stiffness of standing tree trunks (modulus of elasticity, MOE). There are moderate or good relationships between trunk MOE and MOE based on destructive samples successively sawn in the study stems: the modulomètre is able to rank genetic units for a trait related to the MOE of the wood of the stem. Our study showed that there exists a strong genetic effect on trunk MOE. This trait and the MOE measured on destructive samples are moderately related (best $r^{2}$ from 0.37 to 0.42 ) with ring density parameters (based on trimming the ring in two parts: earlywood and latewood), and closely related (best $r^{2}$ from 0.58 to 0.73 ) with parameters describing the shape of a mean density profile segment, mostly located in the latewood part of the ring. (C Inra/Elsevier, Paris.)
\end{abstract}

genetics / modulus of elasticity / stem mechanics / wood density / Douglas fir

Résumé - Modélisation du module d'élasticité à l'aide de données microdensitométriques : méthodes et effets génétiques. $1^{\text {re }}$ partie. L'Inra a fabriqué une machine servant à mesurer la rigidité du tronc des arbres sur pied (Module d'Elasticité du tronc de l'arbre sur Pied, MEP), inspirée de celle imaginée et construite par Koizumi et Ueda au Japon. Des mesures de module de Young en flexion statique réalisées sur des échantillons de taille variable débités dans les troncs des arbres sur lesquels on a mesuré le MEP sont assez bien ou bien liées avec les mesures sur pied : le modulomètre semble donc capable de classer des unités génétiques pour le module de Young du bois. À partir de la mesure du MEP de cinq clones de douglas $\times$ quatre arbres non sélectionnés sur les propriétés de leur bois, on a mis en évidence l'existence d'un très fort contrôle génétique du MEP. Ce caractère et le module d'élasticité des échantillons destructifs découpés dans les troncs sont modérément liés (les meilleurs $\mathrm{R}^{2}$ vont de 0,37 à 0,42 ) aux paramètres microdensitométriques basés sur la découpe du cerne en bois initial et final, et bien liés (les meilleurs $\mathrm{R}^{2}$ vont de 0,58 à 0,73 ) à des paramètres de polynômes décrivant la forme d'un segment de profil situé plutôt vers la fín (bois final) du cerne. (C Inra/Elsevier, Paris.) génétiques / module d'élasticité / mécanique de la tige / densité du bois / douglas

* Correspondence and reprints

rozenberg@orleans.inra.fr 


\section{INTRODUCTION}

Forest resources in temperate regions of the earth are being converted from rather slow-growing naturally regenerated stands to relatively fast-growing planted stands [20, 37]. This evolution will cause a notable decrease of softwood wood quality $[18,20,21,33$, $36-38,45,51]$. Most tree geneticists think that this decrease in wood quality could be restrained or impeded if wood quality traits were taken into account in breeding programmes (e.g. [1, 3, 28, 34, 48, 50, 52]. Among the wood quality traits of interest, modulus of elasticity (MOE) is one of the most significant $[10,35]$. Nondestructive or indirect methods to assess wood quality on standing stems are of primary interest to the breeder, as trees in genetic tests are often valuable plant material that cannot be felled [40].

Vafai and Farshad [47] attempted to build a machine able to measure the MOE of wood in standing trees. Koizumi and Ueda [24] developed on Japanese larch a non-destructive tree-bending test to evaluate trunk stiffness of approximately the first $2 \mathrm{~m}$ of the stem of standing trees. Langbour [29] demonstrated that the nondestructive trunk MOE measurement was possible to apply to poplars. A bending machine, similar to Koizumi's, was built by Inra ([31], figure 1). Preliminary tests were conducted on Douglas fir clones in order to answer the following questions:

- Various researchers [25, 27, 42-44] found differences among Japanese larch provenances for trunk MOE. Is there genetic variation for trunk MOE in Douglas fir?

- Koizumi [22] noted that standing tree MOE of Japanese larch was closely associated with the MOE of boards sawn in the felled stems, a direct measure for industrial uses. What is the relationship between trunk MOE of Douglas fir and MOE of destructive samples successively sawn in the study trees?

- Identifying wood density parameters strongly linked with MOE would enable efficient indirect selection for MOE. Fujisaki ([14], in Cryptomeria japonica), Gentner ([15], in Picea abies), McKimmy [32] and Choi [9] (both in Pseudotsuga menziesii) observed relationships between ring characteristics and MOE of destructive samples. Takata and Hirakawa [43] reported on relationships between within-ring density parameters and trunk MOE in Japanese larch. What is the relationship among the trunk MOE or the MOE of a board sawn in the trunk on one hand, and wood density parameters of samples sawn in the board on the other hand?

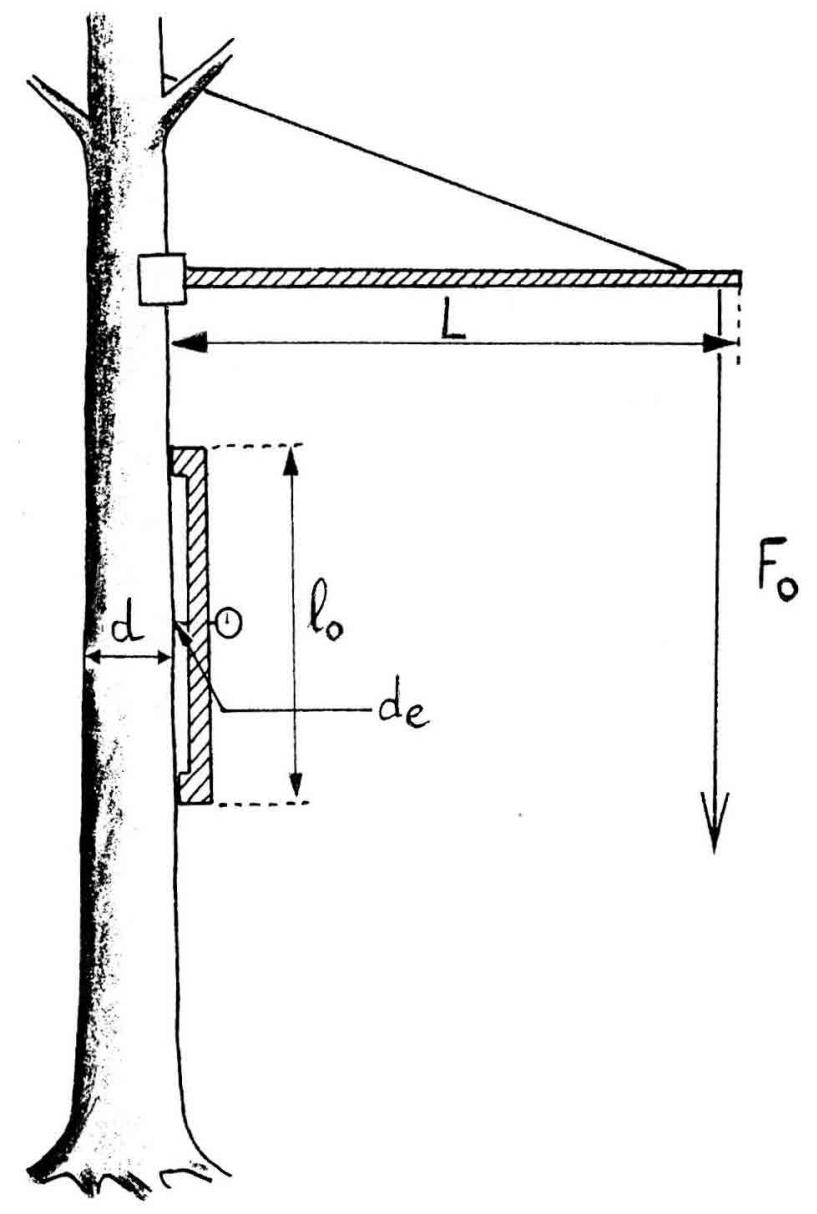

Figure 1. The modulomètre.

\section{MATERIALS AND METHODS}

The plant material consisted of five clones $\mathrm{x}$ four trees per clone, i.e 20 13-year-old Douglas fir cuttings. The 20 sample trees were selected in a clonal test in Peyrat-leChâteau, Limousin (west of Massif Central), France. This region is often thought to be the richest for Douglas fir in France. The selection criteria for the clones and for the trees within the clones were as follows:

\subsection{Diameter at breast height}

Diameter at breast height (DBH) of the trees had to be between the range of use of the machine, i.e. between 10 and $20 \mathrm{~cm}$ for the machine-operator association used in this study. Trees with a very bad shape were eliminated. 
Some clones reserved for future selection were excluded from the sample, as the study trees were going to be felled. After this, trees and clones were selected to scan the full remaining range of variation for height and $\mathrm{DBH}$. The same bending method as as that of Koizumi and Ueda [24] was applied on the selected trees.

\subsection{Data collection and analysis}

- In the field

Figure 1 shows the modulometre. Two bending moments are applied to the stem, in two perpendicular directions. Both deflections are measured at breast height (about $1.3 \mathrm{~m}$ from the ground), and averaged to compensate the error caused by the uneven shape of the cross sections. Diameter is also measured at breast height, over bark, in the two perpendicular directions, and averaged. The shape of the stem is assumed to be cylindrical. Formula (1) was set up by Mamdy [30,31] according to Koizumi and Ueda [24], Koizumi [22] and Langbour [29].

$$
E=\frac{8 \cdot F o \cdot L \cdot l_{0}^{2}}{\pi \cdot d^{4} \cdot d e}
$$

where $E$ is the trunk MOE (MPa), Fo is the strength applied to the stem (N), $L$ is the length of the arm (in $\mathrm{mm}, 1000 \mathrm{~mm}$ here), $l_{0}$ is the length of the holder of the displacement measurement device (in $\mathrm{mm}, 800 \mathrm{~mm}$ here), $d$ is the trunk diameter over bark at breast height $(\mathrm{mm})$ and $d e$ is the recorded displacement $(\mathrm{mm})$.

Diameter ( $d$ in formula (1)) is a very sensible parameter in this formula, and thus has to be measured as accurately as possible. Formula (1) assumes that within the first $2 \mathrm{~m}$ of the stem the MOE variation can be neglected with regard to the between-tree and between-clone variations.

\subsection{Dates of measurement of trunk MOE}

One measurement in July 1994 (0),

three measurements in January 1995 (1, 2 and 3). For the last measurement of January 1995 (3), the arm of the modulomètre was located at $1.7 \mathrm{~m}$ above the ground and at $2.2 \mathrm{~m}$ above the ground during all previous measurements.

Genetic variation and effect of the measurement date and of the height of the arm were studied for trunk MOE with a fixed effect analysis of variance (ANOVA) (MODLI software, an Inra procedure developed by Kobilinsky using S-PLUS statistical software [2]).
$E_{i j k}=\mu+P a_{k}+C l_{j}+A r_{i}+P a \cdot C l_{i k}+P a \cdot A r_{k j i}+\varepsilon_{i j k}$ where $E_{i j k}$ is the MOE measured respectively on the standing trees $\mathrm{Ar}_{\mathrm{i}}$ of clone $\mathrm{Cl}_{\mathrm{j}}$ measured at date $\mathrm{Pa}_{k}, \mu$ is the general MOE mean and $\varepsilon_{\mathrm{ijk}}$ is the residual error.

Trees were felled in January 1995 after the last trunk MOE measurement. Girth was measured at the bottom and the top of the felled trees in order to estimate stem taper and to verify the cylindrical stem assumption. Wood discs were sampled at each end of the stem immediately after the felling of each tree, packed in plastic bags and stored in a cold room, in order to conduct moisture content measurements later in the laboratory.

- In the laboratory

Water content measurements were performed. In each tree, one large board ( $1.7 \mathrm{~m}$ long, $5 \mathrm{~cm}$ thick) was sawn from bark to bark, through the pith, without any reference to the trunk bending direction during the trunk MOE measurement, then dried up to a $12 \%$ water content, using an oven with moisture control. MOE was measured on the boards ( 1 value per tree), using a specially designed 4-points bending machine [31].

Two half-boards were sawn out of each large board (75 $\mathrm{cm}$ long $\times 5 \mathrm{~cm}$ thick, width depending on the diameter of the tree). MOE was measured on the half-boards (two values per tree). On both boards and half-boards, MOE was measured parallel to the ring limits.

Three microdensitometric wood samples were sawn in the samples $(4.2 \mathrm{~cm}$ long $\times 2.4 \mathrm{~cm}$ thick wood blocks, width depending on the tree) taken at each end and in the middle of the large boards (approximately at $0.3,1.3$ and $2.0 \mathrm{~m}$ from the ground). Table I shows the sample number at tree, clone and general level, as well as the measurements.

All samples were air-dried to a $12 \%$ water content.

One radial X-ray, density profile was recorded on each sample using the indirect $\mathrm{X}$-ray microdensitometer

Table I. Measurements and sample number at the tree, clone and general levels.

\begin{tabular}{lccc}
\hline Measurement & Stem level & Clone level & Total \\
\hline Trunk MOE & 1 & 4 & 20 \\
Board MOE & 1 & 4 & 20 \\
X-ray profiles on boards & 3 & 12 & 60 \\
Standard sample MOE & 4 & 16 & 80 \\
X-ray profiles on standard & 4 & 16 & 80 \\
samples & & & \\
\hline
\end{tabular}

MOE: modulus of elasticity. 
Table II. Minimum number of study rings in the board's X-ray density profiles.

\begin{tabular}{lccc}
\hline Height of X-ray sample in the tree & $0.3 \mathrm{~m}$ & $1.3 \mathrm{~m}$ & $2.0 \mathrm{~m}$ \\
Minimum number of rings common to all trees & $9(1986-1994)$ & $7(1988-1994)$ & $7(1988-1994)$ \\
\hline
\end{tabular}

described by Polge [39]. The original microdensitometer was significantly improved to speed up data recording. Table II show the minimum number of rings studied in the board's X-ray density profiles:

Two standardised wood samples $(36 \mathrm{~cm} \times 2 \mathrm{~cm} \times$ $2 \mathrm{~cm}$, according to the French norm NF B50-008) were sawn in each half-board.

MOE was measured on the standardised wood samples ( 4 values per tree), strength direction parallel to the ring limits, using the method described by Mamdy [31] and the following formula (2) [16]:

$$
E=\frac{3 \cdot p \cdot(H-L) \cdot l_{0}^{2}}{8 \cdot d \cdot e^{3}}
$$

where $E$ is the MOE (MPa) $p$ is the slope of the straight line describing the relationship between the applied strength $(\mathrm{N})$ and the measured displacement $(\mathrm{mm}) ; d$ and $e$ are respectively the width and the thickness of the wood sample (mm); $H$ is the distance between the two supports $(\mathrm{mm}) ; L$ is the distance between the two application points of the strength $(\mathrm{mm})$, and $l_{o}$ is the distance between the two supports of the displacement measurement device $(\mathrm{mm})$.

Figure 2 illustrates the samples and the measurements conducted on these samples.

A correlation study was conducted on MOE data and density values derived from $\mathrm{X}$-ray density profiles. Two types of density values were calculated: 1) called here classical within-ring density parameters (ring width and ring density, minimum and maximum ring density, early and latewood width and early and latewood density, as calculated by Choi [9], Takata and Hirakawa [43] and many others) and 2) coefficients of polynomials describing wood density variations in a selected part of a mean ring profile (see the Results section for the description of the best found polynomials coefficient). The mean ring profile was calculated using part of or all the rings of a tree, standardised to a given number of points ( 40 here), and averaged. All data treatment was conducted using original S-PLUS procedures [41].

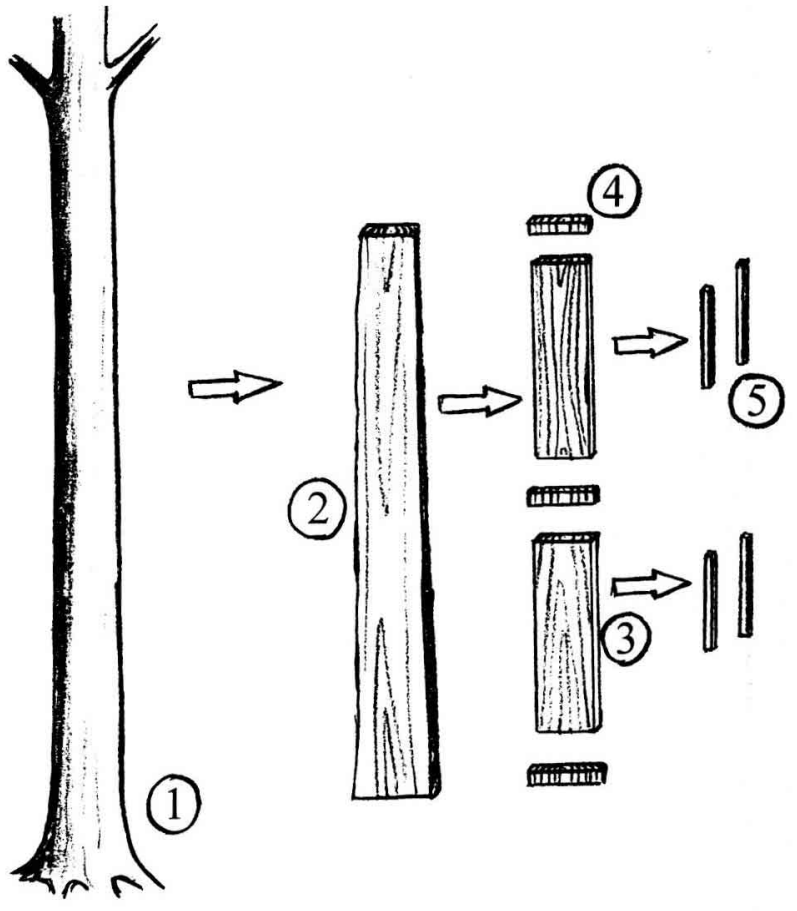

Figure 2. The trunk and the samples saw in the trunk: (1): trunk; (2): large board; (3): half-boards; (4): microdensitometric samples and (5): standard samples.

\section{RESULTS}

\subsection{Estimation of the trunk MOE}

The trunk MOE values range from approximately 7000 to $11000 \mathrm{MPa}$, whereas according to Guitard [16], MOE estimated on standard (destructive) Douglas fir wood samples is estimated to range from 12300 to $16800 \mathrm{MPa}$, This difference could be partly linked to the fact that the moisture content of the standing trees is between 81 to $110 \%$ in January 1995, while MOE measurements are usually conducted on wood samples at a moisture content of $12 \%$. 
Table III. Variability among trees (standard deviation $\mathrm{s} /$ mean $\mathrm{m}$ ) for $d e, F_{o} / d e$ and $E$ (see formula (1)).

\begin{tabular}{lcccc}
\hline$\sigma / \mu$ & July 1994 & January $1995(1)$ & January 1995 (2) & January 1995 (3) \\
\hline$d e$ & 0.63 & 0.62 & 0.60 & 0.60 \\
$F_{o} / d e$ & 0.72 & 0.65 & 0.70 & 0.71 \\
$E$ & 0.15 & 0.11 & 0.10 & 0.10 \\
\hline
\end{tabular}

The precision of the estimation of the trunk MOE is limited by the precision of the measurement of $d e$ and, overall, $d$ (formula (1)). About $80 \%$ of the variability among trees for de is explained by the differences among trees for $d$ (table $I I$ ). The remaining variability for $E$ is low (as stated by Zobel and Van Buijtenen [51] and Cornelius [11], the variability for wood quality traits is often lower than the variability for other traits such as growth traits). Table III presents the variability among trees (standard deviation s/mean $\mathrm{m}$ ) for de, $F_{0} / d e$ and $E$ (see formula (1)).

The repeatability of the estimation of the trunk MOE is good, between 0.89 and 0.96 ( $P$ value $<0.001$ ), even when the arm of the modulometre is moderately shifted from 2.2 to $1.7 \mathrm{~m}$ (January (3), table $I I I)$.

Table IV shows the relationships between trunk MOE measurements made at different dates. The correlation coefficients are very high among the measurements made in January. There are smaller, yet still high coefficients between the July and the January measurements.

There is no relationship between the stem taper and the MOE: therefore, the cylindrical stem assumption cannot be rejected. Nor is there a relationship between the trunk MOE and the water content of the stem at the time of measurement. This observation is consistent that of with Guitard [16], who stated: "Over a $30 \%$ water content, the fibre saturation point is over passed, and the modulus of elasticity levels off" (measured water content values were between 81 and $122 \%$ ).

\subsection{Genetic effect on the trunk MOE}

In table $V$, the data from the July 1994 measurements were excluded from the analysis. There is no effect of the date of measurement. A very high clonal effect is the main effect, despite the relatively low number of clones and the lack of data about the wood quality of the selected clones when they were chosen.

When data from July 1994 is included in the analysis, there is a strong effect of the date of measurement; however, this effect is far weaker than the clonal effect.
Table IV. Relationships between trunk modulus of elasticity (MOE) measurements made at different dates.

\begin{tabular}{ccc} 
July 1994 & $\begin{array}{c}\text { January } 1995 \\
(1)\end{array}$ & $\begin{array}{c}\text { January } 1995 \\
(2)\end{array}$ \\
\hline $0.84 * * *$ & & \\
$0.86 * * *$ & $0.90 * * *$ & \\
$0.82 * * *$ & $0.89 * * *$ & $0.96 * * *$
\end{tabular}

Repeatability measured with linear correlation coefficient; $* * *$ indicates $P$ value $<0.001$.

Table $V$ gives the results of the analysis de variance conducted on the trunk MOE data. The accuracy of the trunk MOE measurement makes it possible to establish a very strong genetic effect on the trunk MOE.

Figure 3 presents trunk MOE estimations at tree, clone and date of measurement levels. There is also a significant date clone and date tree-clone interaction, but this interaction has little effect on the ranking of the clones and trees from one date of measurement to another (figure 4).

\subsection{Relationships between trunk MOE and destructive samples MOE}

Figure 5 presents the relationships among MOE values of standing trunks, large boards, half-boards and standardised samples. The trunk MOE is mainly linked with the large board $\mathrm{MOE}$ and the mean of the two top standard samples. There is a good relationship between the large board MOE and both means of the two halfboards and of the four standard samples. There is no relationship between the top and bottom samples, nor between the trunk MOE and the bottom samples.

\subsection{Relationships between MOE and classical within-ring density parameters}

These relationships are shown in table VI and are presented as null, low or moderate. The strongest relation- 
Table V. Results of the analysis de variance conducted on the trunk modulus of elasticity (MOE) data.

\begin{tabular}{lccccc}
\hline $\begin{array}{l}\text { MOE } \\
\text { Source of variation }\end{array}$ & $\begin{array}{c}\text { Sum of squared } \\
\text { deviations (MPa) }\end{array}$ & Degrees of freedom & Mean squares & & \\
\hline $\mathrm{Cl}$ & $0.2970 .10^{9}$ & 4 & $0.73 .10^{8}$ & 246.2 & $<$ value \\
$\mathrm{Ar}$ & $0.3956 .10^{9}$ & 15 & $0.26 .10^{7}$ & 87.4 & $<0.00$ \\
$\mathrm{~Pa}$ & $0.3973 .10^{7}$ & 2 & $0.20 .10^{7}$ & 6.6 & 0.19 \\
$\mathrm{Cl} / \mathrm{Pa}$ & $0.1330 .10^{8}$ & 8 & $0.16 .10^{7}$ & 5.5 & $<0.00$ \\
$\mathrm{Ar} / \mathrm{Pa}$ & $0.3289 .10^{7}$ & 30 & $0.11 .10^{7}$ & 3.6 & $<0.00$ \\
Residual error & $0.1620 .10^{9}$ & 537 & $0.30 .10^{6}$ & & $<0.00$ \\
Model & $0.7428 .10^{9}$ & 59 & $0.21 .10^{8}$ & 41.7 & \\
Total & $0.9047 .10^{9}$ & 596 & $0.15 .10^{7}$ & &
\end{tabular}

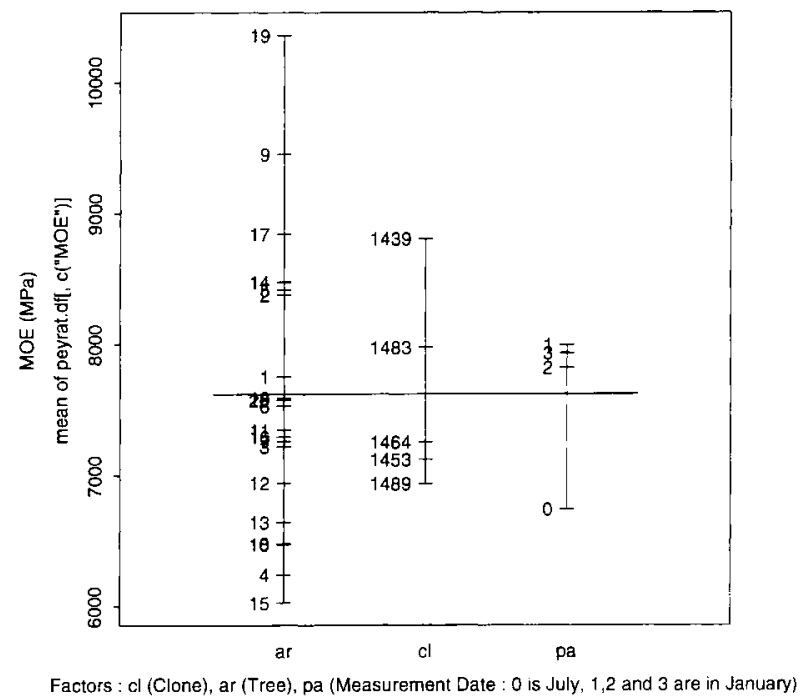

Figure 3. Clone (from 1439 to 1489), tree (from 1 to 20) and measurement-date (from 0 to 3 ) variability for the trunk modulus of elasticity (MOE).

ships are those between the trunk MOE and the mean ring density, $\left(r^{2}=0.42 * *\right)$ and between the board MOE and the latewood width $\left(r^{2}=0.37^{* *}\right)$.

\subsection{Relationships between MOE and parameters of polynomials describing the shape of a segment of the ring density profile}

Linear correlation coefficients between the density of each point in the mean adjusted ring density profile (ring width adjusted to 40 density values; see the Materials

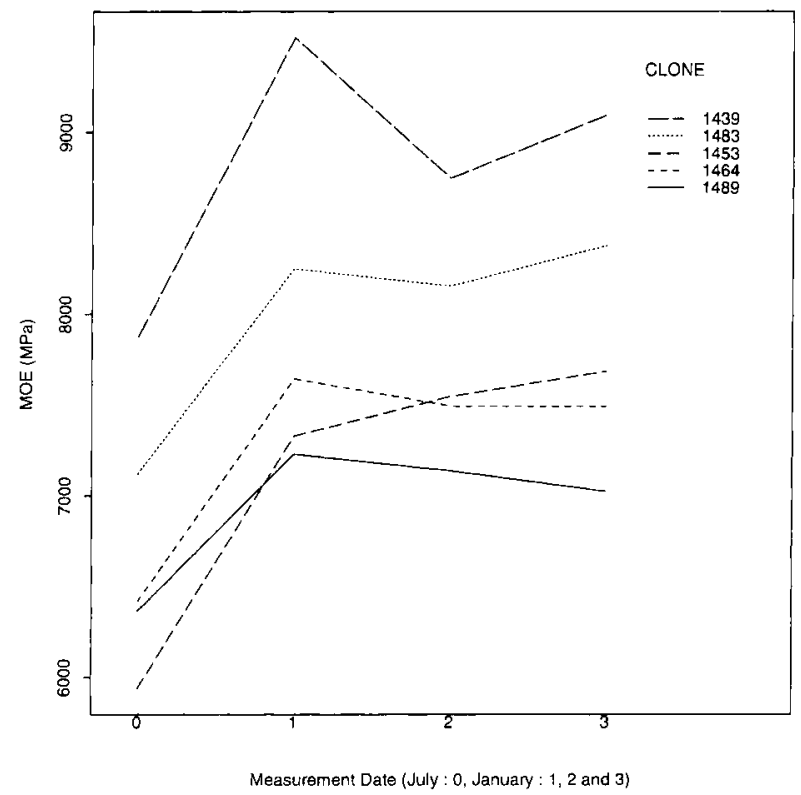

Figure 4. Measurement dates at clone level interaction.

and Methods section) and respectively trunk and large board MOE were calculated. Figure 6 shows the evolution of this linear correlation coefficient along the ring. The relationship is low in the first part of the ring (earlywood) and moderate (trunk) or high (board) in the second part of the ring. The segment of the ring in which the relationship was higher was selected (points 18 to 31 for the trunks and 19 to 39 for the boards), and modelled using a third-degree orthogonal polynomial. Then the best multiple linear model (according to the stepwise efroymson method [41]) describing the relationship between the MOE and the parameters of the polynomials 
Graph 5.1

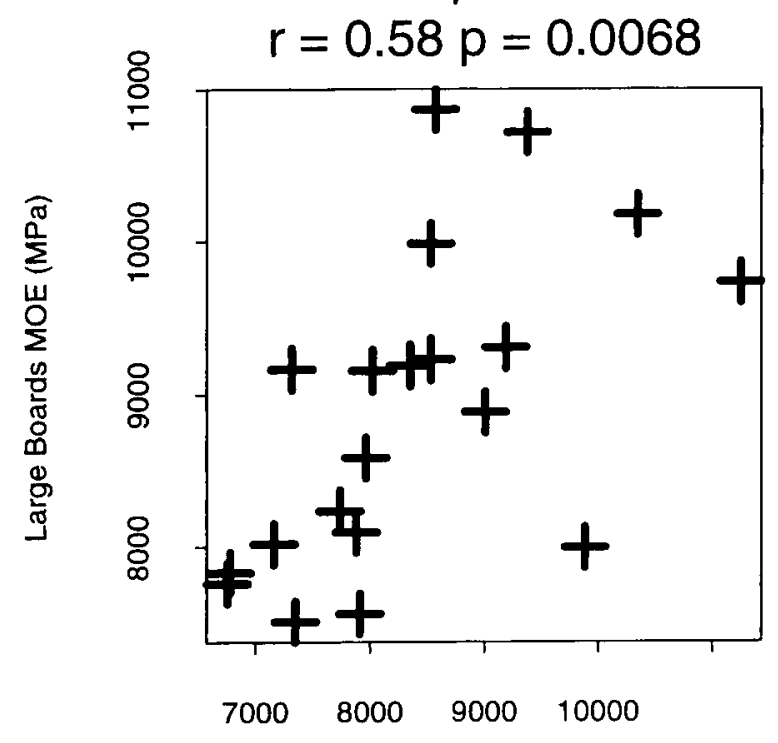

Trunk MOE (MPa)

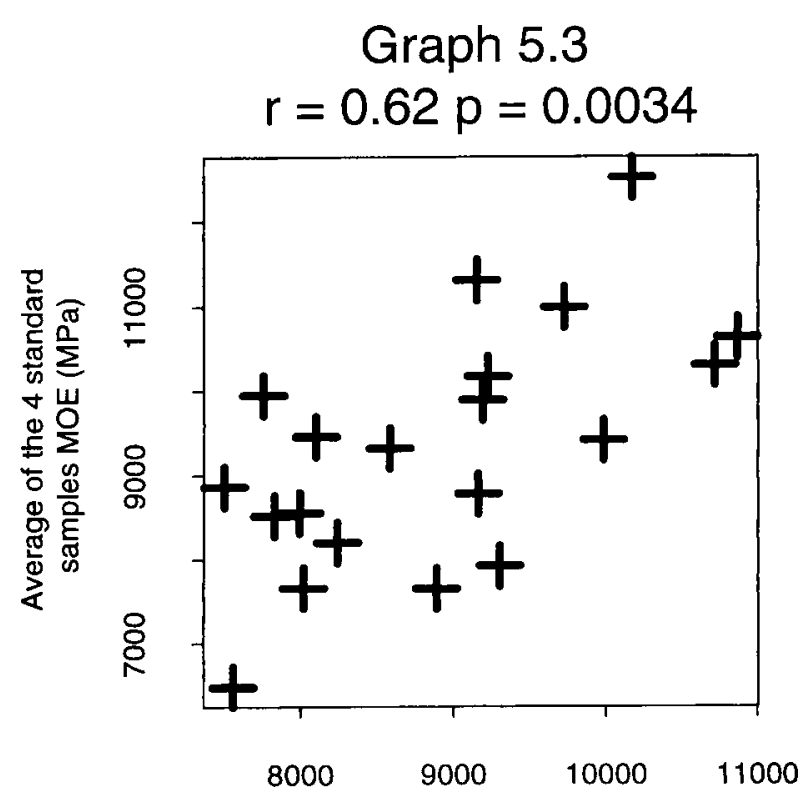

Large Boards MOE (MPa)

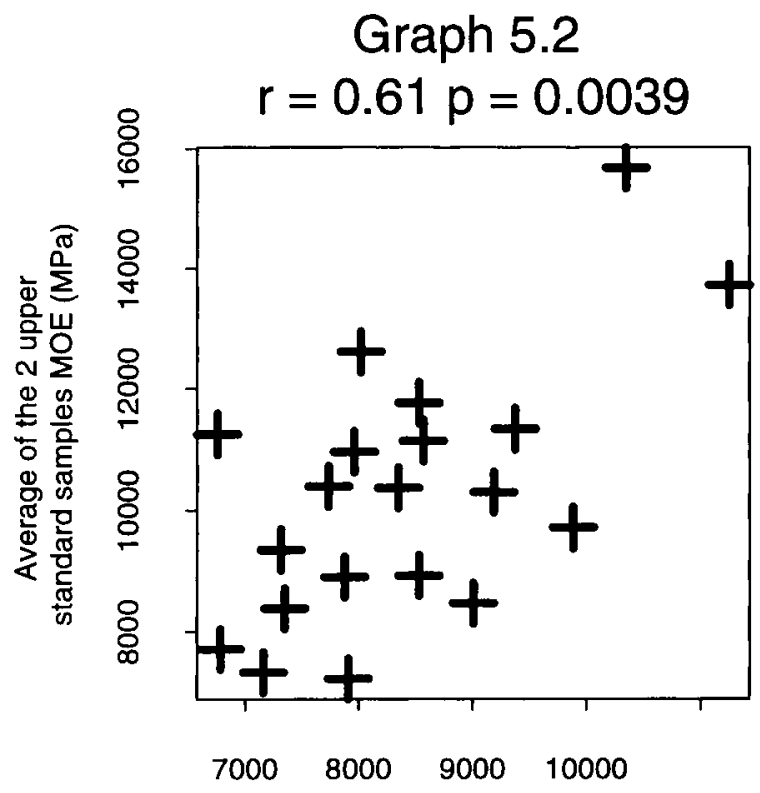

Trunk MOE (MPa)

Graph 5.4

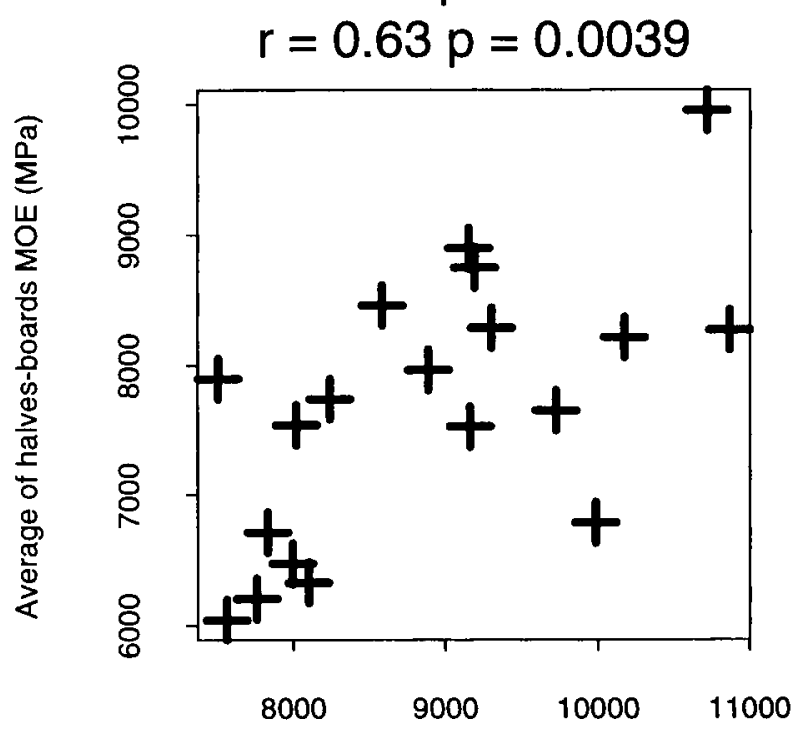

Large Boards MOE (MPa)

Figure 5. Relationships among trunk, board, halves-board and standard-sample modulus of elasticity (MOE). 
Table VI. Relationships between modulus of elasticity (MOE) and classical within-ring density parameters.

\begin{tabular}{lcccccccc}
\hline$r^{2}$ & $\begin{array}{c}\text { Ring } \\
\text { width }\end{array}$ & $\begin{array}{c}\text { Earlywood } \\
\text { width }\end{array}$ & $\begin{array}{c}\text { Latewood } \\
\text { width }\end{array}$ & $\begin{array}{c}\text { Latewood } \\
\text { proportion }\end{array}$ & $\begin{array}{c}\text { Ring } \\
\text { density }\end{array}$ & $\begin{array}{c}\text { Earlywood } \\
\text { density }\end{array}$ & $\begin{array}{c}\text { Latewood } \\
\text { density }\end{array}$ & $\begin{array}{c}\text { Density standard } \\
\text { deviation }\end{array}$ \\
\hline Trunk MOE & $0.06 \mathrm{~ns}$ & $0.13 \mathrm{~ns}$ & $0.07 \mathrm{~ns}$ & $0.13 \mathrm{~ns}$ & $0.42^{* *}$ & $0.01 \mathrm{~ns}$ & $0.00 \mathrm{~ns}$ & $0.28^{*}$ \\
Large board MOE & $0.03 \mathrm{~ns}$ & $0.02 \mathrm{~ns}$ & $0.37^{* *}$ & $0.26^{*}$ & $0.19^{*}$ & $0.06 \mathrm{~ns}$ & $0.26^{*}$ & $0.26^{*}$ \\
\hline
\end{tabular}

ns: not significant; *: significant at $P=0.05$ level; **: significant at $P=0.01$.

Board MOE

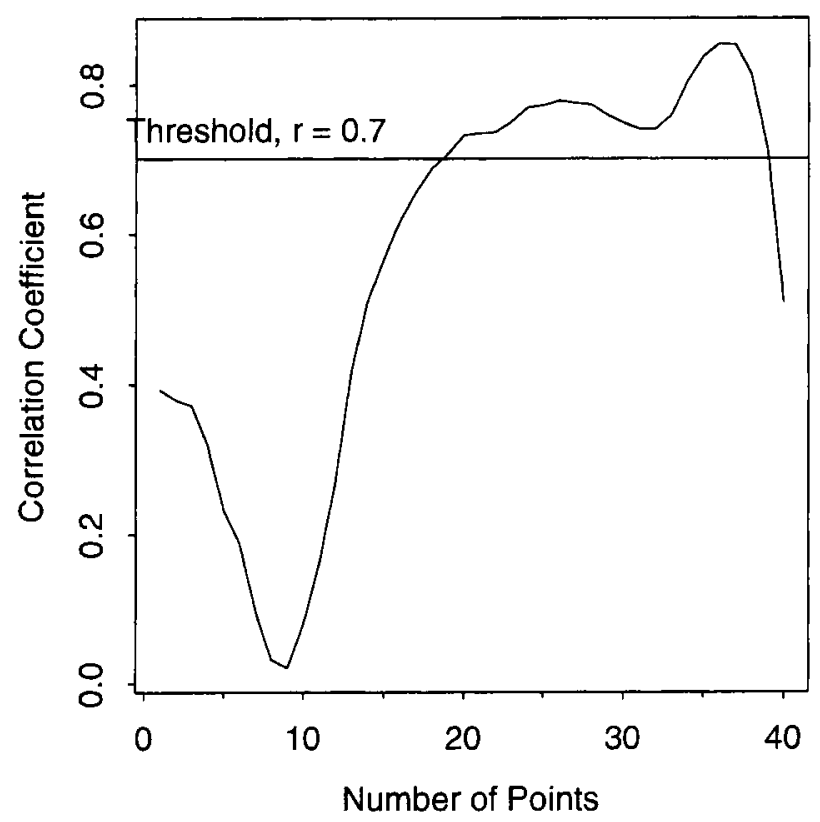

Trunk MOE

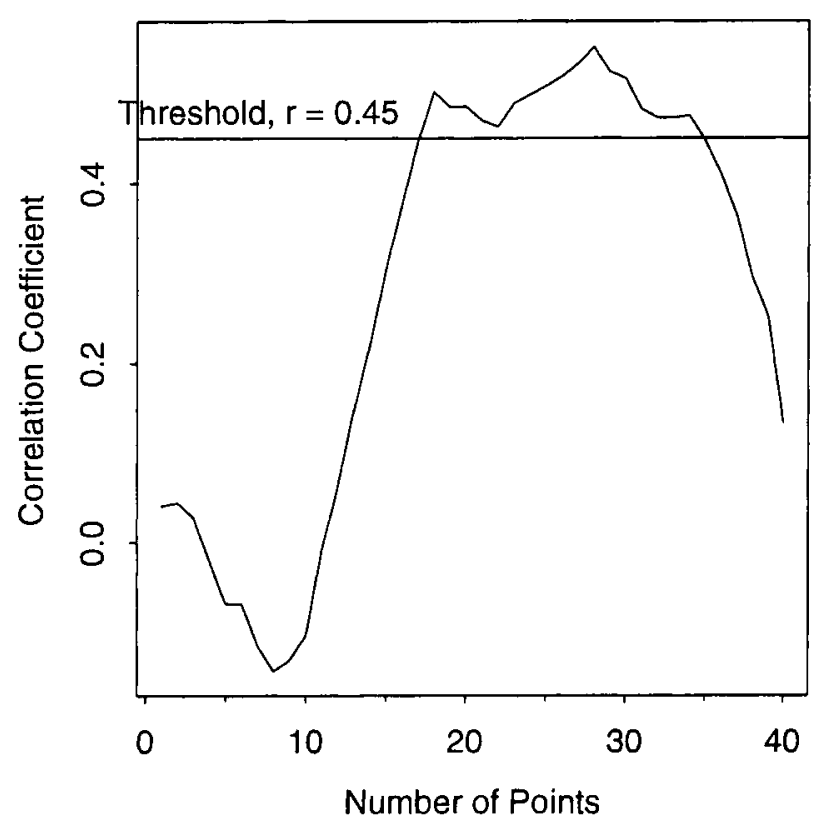

Figure 6. Evolution of the correlation coefficient between the mean ring local density values and the modulus of elasticity (MOE) drawn against its position in the ring. Left graph: the relationship between board MOE and the local density in the mean ring. Right graph: the relationship between trunk MOE and the local density in the mean ring.

was calculated. The results are shown in table VII. This table also gives the results of the regression analysis between the MOE and the density parameters. The polynomial is $y=a_{0}+a_{1} \cdot x+a_{2} \cdot x^{2}+a_{3} x^{3}$ (where $y$ is the density and $x$ is the position along the selected ring segment). There are highly significant relationships among trunk (and board) MOE and parameters of polynomial describing the density variations of a given ring density segment (pol parameters). These relationships are stronger than those with the classical within-ring parameters ( $r^{2}$ increases from 0.42 to 0.58 for trunk MOE and from 0.37 to 0.73 for board MOE). This segment is mainly located in the latewood. Values of multiple $r^{2}$ range from $0.58^{* * * *}$ to $0.80^{* * *}$, according to the number of polynomial coefficients involved in the relationship. Two of the three presented relationships are simple linear ones, and the explicative variable is $a_{0}$, i.e. the value of the intercept in the $Y$-axis (which is very close to the density of the first point of the selected density segment).

\section{DISCUSSION AND CONCLUSION}

As reported by Koizumi and colleagues [22, 25-27], Takada et al. [42] and Takata and co-workers [42-44], there is a highly significant genetic effect for trunk MOE 
Table VII. Results of the regression analysis between the modulus of elasticity (MOE) and the density parameters.

\begin{tabular}{|c|c|c|c|c|c|c|}
\hline Trait & $\begin{array}{l}\text { Rings } \\
\text { used to } \\
\text { calculate } \\
\text { the mean } \\
\text { tree profile }\end{array}$ & $\begin{array}{l}\text { Height of } \\
\text { the profiles } \\
\text { used to calculate } \\
\text { the mean tree } \\
\text { profile }(\mathrm{m})\end{array}$ & $\begin{array}{l}\text { Selected points } \\
\text { in the mean } \\
\text { ring }\end{array}$ & $\begin{array}{l}\text { Best multiple } \\
\text { regression } \\
\text { model }\end{array}$ & Method & Multiple $r^{2}$ \\
\hline Trunk MOE & $1987-1993$ & 2.0 & $18-31$ & $\mathrm{MOE}=\alpha a_{0}$ & Efroymson & $0.58 * * *$ \\
\hline Board MOE & $1986-1993$ & 1.3 & $19-39$ & $\mathrm{MOE}=\alpha a_{0}$ & Efroymson & $0.73 * * *$ \\
\hline
\end{tabular}

The polynomial is $y=a_{0}+a_{1} x+a_{2} x^{2}+a_{3} x^{3}$ (where $y$ is the density and $x$ is the position along the selected ring segment); ***: significant at $P=0.001$.

in the study sample (table V). Presently, 20 trees/day are measured with the modulometre. Technical improvement of the machine may increase this figure to $40-50$ trees/day. This is sufficient for the final selection of individuals in a progeny test, in the framework of a breeding programme.

There are significant relationships between trunk MOE and MOE of different types of destructive samples sawn in the trunk (figure 5). Therefore, the modulomètre is able to rank trees and genetic units for a trait related to the MOE of the wood of the first $2 \mathrm{~m}$ of the stem of standing Douglas fir, i.e. of the most valuable part of these trees. The strongest relationship between the trunk MOE and a destructive sample MOE is obtained with the mean of the 2 top standard samples. Sawing one sample between 1.3 and $2.0 \mathrm{~m}$, or two samples from under $1.3 \mathrm{~m}$ was not enough to estimate the global trunk MOE. Of course, these results were obtained on only 20 trees of one species, and have to be confirmed.

While highly significant, the relationships between trunk MOE and destructive samples MOE are in general only moderate. Different factors may affect these relationships.

- A lack of precision in the estimation of the trunk diameter.

- Confusion between wood and bark, which are materials of different stiffness.

- In the bending stem, rings are roughly circular, and thus progressively turn from being parallel to being perpendicular to the applied strength. In the destructive samples, in our tests, rings are always parallel to the direction of strength. Physical models taking that point into account may help increase the strength of our relationships. For example, the destructive samples can be considered as heterogeneous beams, with several layers of different densities and MOEs. A beam can be loaded either parallel (a) or perpendicular (b) to the ring limits. The rigidity of a layered beam may be expressed as:

$$
\overline{E I}=\sum_{i} E_{i} I_{i}
$$

where $I_{i}$ is the moment of inertia and $E_{i}$, the MOE of the cross section of the layer $i$, In case (a), $I_{i}$ is constant if all layers have same width and height. In case (b), $I_{i}$ is higher for the upper or lower layers of the beam cross section. The MOE of the outer layers has a higher weight than that of the inner layers. The sample rigidity will be higher if the outer ring has a higher MOE. Case (a) is the usual test method. If we assume that the $E_{i}$ variation rate is periodic and that $I_{i}$ is constant, then the deflection of an heterogeneous beam will be the same as the deflection of an homogeneous beam whose MOE equals the mean of $E[4,13]$.

As reported by various authors $[9,14,15,32,43]$, highly significant relationships were found between trunk or board MOE, and ring parameters. $r^{2}$ values for individual relationships between MOE and classical within-ring parameters are slightly lower in our study than those in Fujisaki's [14], Choi's [9] and Takata and Hirakawa's [43]. In our study (table VI), the highest is 0.42 , whereas it reaches $0.53,0.54,0.45$ and 0.55 respectively in the studies done by Fujisaki ([14], with ring width), Gentner ([15], with latewood proportion), Choi ([9], with latewood proportion) and Takata and Hirakawa ([43], 0.54 with latewood proportion and 0.55 with ring density). The overall highest $r^{2}$ for individual and multiple relationships are found for our study's relationship between MOE and the pol parameters. The part of the ring most involved in these relationships is, for the trunk MOE, the transition zone between early and latewood and the first part of the latewood. For the board MOE, the transition zone and nearly all latewood are 
involved: MOE is high when density is high in the beginning of the second part of the ring. As a result, the modulometre seems to be an interesting tool to calibrate a model predicting the trunk MOE from parameters derived from X-ray density profiles. Moreover, it is possible that the modulometre, combined with other nondestructive methods (such as ultrasonics or especially vibration methods [17]), can indirectly estimate the MOE of future sawn samples.

The method used to sum up the vast amount of information in an X-ray density profile is simple, but seems to give far better results than trying to relate the classical within-ring parameters with the MOE (tables VI and $V I I)$ : it is likely that more progress is possible, and that most, or all of the variation for MOE can be explained using data about biomass accumulation in the stem. Part II of this report concentrates on the relationship between MOE and some simple density parameters with a clearer physical meaning than parameters from polynomials describing within-ring density profiles. It also explores the genetic variability of these relationships.

Ultimately, the modulometre is not only a nondestructive machine, but also a cheap device, compared to other tools used to assess MOE or to record density profiles.

Acknowledgements: We wish to warmly thank Dr. Akio Koizumi for his help all along this study.

\section{REFERENCES}

[1] Akachuku A.E., The possibility of tree selection and breeding for genetic improvement of wood properties of Gmelina arborea, For. Sci 30 (1984) 275-283.

[2] Anonymous, MODLI, BAO/document $n^{\circ} 09 / 90$, NCY/GL, Département d'informatique, Inra, France, 1990, $21 \mathrm{p}$.

[3] Birot Y., Nepveu G., Variabilité clonale et liaison ortetramets dans une population d'épicéa, Silvae Genet. 28 (1979) $37-47$.

[4] Bodig J., Jayne B., Mechanics of Wood and Wood Composites, Van Nostrand Reinhold Co., 1982.

[5] Bunn E.H., The nature of the resource. New Zeal. J. For. 26 (1981) 162-169.

[6] Cave I.D., Walker J.C.F., Stiffness of wood in fastgrown plantation softwoods - the influence of the microfibril angle, For. Prod. J. 44 (5) (1994) 43-48.

[7] Chantre G., Liaison entre rigidité et densité du bois à l'intérieur du cerne. Application au cas de l'épicéa commun (Picea abies Karst.), rapport de DEA sciences du bois, INPL Nancy, France, 1989, 46 p.

[8] Chantre G., Gouma R., Influence du génotype, de l'âge et de la station sur la relation entre l'infradensité du bois et la vigueur chez l'épicéa commun (Picea abies Karst.), Ann. Rech Sylv. 1993-1994, Afocel, France, 1994.

[9] Choi A.S.C., Correlation between mechanical strength of wood and annual ring characteristics in Douglas-fir juvenile and mature wood, Master of Science thesis, Oregon State University, OR, 1986, 84 p.

[10] Collardet J., Besset J., Bois commerciaux, Tome I. Les résineux (conifères), Editions $\mathrm{H}$. Vial et Centre technique du bois et de l'ameublement, Paris, France, 1988, p.277.

[11] Cornelius J., Heritabilities and additive genetic coefficients of variation in forest trees, Can. J. For. Res. 24 (1994) 372-379.

[12] Elliott G.K., Wood Density in Conifers, Technical Communication $n^{\circ} 8$, Commonwealth Forestry Bureau, Oxford, England, 1970, p. 44.

[13] Fournier M., Mécanique de l'arbre sur pied : poids propre, contraintes climatiques et maturation dans la tige standard, thèse, INP de Lorraine, Sciences du bois, France, 1989.

[14] Fujisaki K., Multiple regression analysis of the MOE of Sugi wood using cambial age and ring width as predictor variable, Bull. Ehimi University For. 20 (1984) l-6.

[15] Gentner R., Appréciation non destructive de la qualité du bois d'arbres sur pied : cas de l'épicéa de Sitka (Picea sitchensis (Bong.) Carr.), rapport ERQB Inra Nancy, Enitef, France, 1985, p. 98.

[16] Guitard D., Mécanique du matériau bois et composites, Cepadues éditions, 1987, $236 \mathrm{p}$.

[17] Haines D.W., Leban J., Herbé C., Determination of Young's modulus for spruce, fir and isotropic materials by the resonance flexure method with comparison to static flexure and other dynamics methods, Wood Sci. Technol. 30 (1996) 253-263.

[18] Johansson F., Nyhlén F., Yngvesson M., Wood quality from planted and naturally regenerated spruce on good sites in southern Sweden, in: Hagner M. (Ed.), Silvicultural Alternatives. Proceedings from an Internordic Workshop, 22-25 June 1995, Umea, Sweden, 1992, pp.149-151.

[19] Johansson G. Kliger I.R., Perstorper M., Structural sawn timber quality requirements, Struct. Eng. Int. (IABSE) 3 (2) (1993) 99-103.

[20] Kennedy R.W., Coniferous wood quality in the future: concerns and strategies, Wood Sci. Technol. 29 (1995) 321-338.

[21] Kliger I.R., Perstorper M., Johansson G., Pellicane P.J., Quality of timber products from Norway Spruce, Part 3. Influence of spatial position and growth characteristics on bending stiffness and strength, Wood Sci. Technol. 29 (1995) $397-410$.

[22] Koizumi A., Studies on the estimation of the mechanical properties of standing trees by non-destructive bending test, Bull. College Experiment Forest, Faculty of Agriculture, Hokkaido University, 44 (4) (1987) 1329-1415.

[23] Koizumi A., Variability in wood quality of Japanese larch observed by tree bending tests, 19th IUFRO Congress, Montreal, Canada, 1990, 1990, 7 p. 
[24] Koizumi A., Ueda K., Estimation of the mechanical properties of standing trees by bending tests, Mokuzai Gakkaishi 32 (9) (1986) 669-676.

[25] Koizumi A., Takada K., Ueda K., Katayose T., Radial growth and wood quality of plus trees of Japanese larch. I. Radial growth, density, trunk modulus of elasticity of grafted clones, Mokuzai Gakkaishi 36 (2) (1990) 98-102.

[26] Koizumi A., Takada K., Ueda K., Radial growth and wood quality of plus trees of Japanese larch. II. Diameters at breast heights and trunk moduli of elasticity of 18-year-old offspring families, Mokuzai Gakkaishi 36 (9) (1990) 704-708.

[27] Koizumi A., Takada K., Ueda K., Variation in modulus of elasticity among japanese larch from different provenances, Proceedings of the IUFRO Working Party S2.02-07, Berlin 512/09/1992, 1992, pp. 66-72.

[28] Lacaze J.F., Polge H., Relations phénotypiques au stade juvénile entre la densité du bois et divers caractères phénologiques et de vigueur chez Picea abies Karst, Ann. Sci. For. 27 (3) (1970) 231-242.

[29] Langbour P., Rigidité de l'arbre sur pied, indicateur de l'élasticité longitudinale du bois. Application aux peupliers, thèse INPL, Inra Nancy, France, 1989, 136 p.

[30] Mamdy C., Étude et amélioration d'un appareil servant à mesurer le module d'élasticite de tronc d'arbres sur pied, rapport de stage ESEM, Inra Orléans, France, 1994, 36 p.

[31] Mamdy C., Contribution à l'étude du module d'élasticite de troncs d'arbres sur pied; utilisation en amélioration génétique des arbres forestiers, rapport de DEA matières condensées et diluées, ESEM, Inra Orléans, France, 1995, 47 p.

[32] McKimmy M.D., The effect of intra-ring microcharacteristics on mechanical properties of young-growth Douglas-fir wood. Fifth Symposium on Non-destructive Testing of Wood, Washington State University, Seattle, WA, 1985.

[33] Mothe F., Aptitude au déroulage du bois de Douglas. Conséquences de l'hétérogénéité du bois sur la qualité des placages, thèse de l'Institut polytechnique de Lorraine, Inra Nancy, France, 1988, 98 p.

[34] Nepveu G., Variabilité génétique de la qualité du bois chez l'épicéa et le douglas, Rev. For. Fr. 36 (4) (1984) 303-312.

[35] Nepveu G., La variabilité du bois in le matériau bois, 2e édn., ARBOLOR, Nancy, 1991.

[36] Perstorper M., Pellicane P.J., Kliger I.R., Johansson G., Quality of timber products from Norway Spruce, Part 1, Optimization, key variables and experimental study, Wood Sci. Technol. 29 (1995) 157-170.

[37] Perstorper M., Pellicane P.J., Kliger I.R., Johansson G., Quality of timber products from Norway Spruce, Part 2, Influence of spatial position and growth characteristics on warp, Wood Sci. Technol. 29 (1995) 339-352.
[38] Petty J.A., Macmillan D.C., Steward C.M., Variations of density and growth ring width in stems of Sitka and Norway Spruce, Forestry 63 (1) (1990) 39-49.

[39] Polge H., Établissement des courbes de variation de la densité du bois par exploration densitométrique de radiographies d'échantillons prélevés à la tarière sur des arbres vivants. Application dans les domaines technologiques et physiologiques, thèse, Université de Nancy, France, 1966, 206 p.

[40] Rozenberg P., Cahalan C., Spruce and wood quality: genetic aspects (a review), Silvae Genet. 46 (1997) 270-249.

[41] Statistical Sciences, S-PLUS Guide to Statistical and Mathematical Analysis, Version 3.2, Seattle, StatSci, a division of MathSoft, Inc., 1993.

[42] Takada K., Koizumi A., Ueda K., Geographic variation in the moduli of elasticity of tree trunks among Japanese larch in provenance trial-stands, Mokuzai Gakkaishi, 38 (3) (1992) 222-227.

[43] Takata K., Hirakawa Y., Variation in growth parameters among Japanese larch from different provenances, communication presented at the Third Pacific Region Wood Anatomy Conference, 1994, $13 \mathrm{p}$.

[44] Takata K., Ueda K., Koizumi A., Geographic variation in modulus of elasticity of tree trunks among Japanese larch planted in Hokkaido, in: Proceedings of the Larix International Symposium, Ecology and Management of Larix Forests: A Look Ahead, May 1995, 1995, pp. 502-504.

[45] Thompson D.A., Growth of Sitka spruce and timber quality, in: Rook D.A. (Ed.), Super Sitka for the 90s, For. Comm. Bull. 103 (1992) 54-60.

[46] Thörnqvist T., Juvenile wood in coniferous trees, Document D13:1993, Swedish Council for Building Research, Stockholm, Sweden, 1993, $110 \mathrm{p}$.

[47] Vafai A., Farshad M., Modulus of elasticity of wood in standing trees, Wood Sci. 12 (2) (1979) 93-97.

[48] Vargas-Hernandez J., Adams W.T., Krahmer R.L., Family variations in age trends of wood density in wood density in young coastal Douglas-fir, Wood Fiber Sci. 1994.

[49] Woxblom L., Raw material selection and adaptation of sawing patterns in order to meet product requirements of the construction sector, Second IUFRO Workshop: Connection Between Silviculture and Wood Quality Through Modelling Approaches and Simulation Software, Kruger National Park, South Africa, 26-31 August, 1996.

[50] Zhang S.Y., Effect of growth rate on wood specific gravity and selected mechanical properties in individual species from distinct wood categories, Wood Sci. Technol. 29 (1995) 451-465.

[51] Zobel B.J., Van Buijtenen H., Wood Variation: Its Causes and Control, Springer-Verlag, Berlin, 1989, 363 p.

[52] Zobel B.J., Jett B.J., Genetics of Wood Production, Springer-Verlag, Berlin, 1995, 337 p. 